\title{
References:
}

1. Гуревич М. А. Хронічна ішемічна (коронарна) хвороба серця. Москва, 2003. 192 с.

2. Серцево-судинні захворювання. Класифікація, стандарти діагностики та лікування / За ред. В. М. Коваленка. Київ: Моріон, 2018. $223 \mathrm{c}$.

3. Денесюк B.I., Денесюк О.В. Доказова внутрішня медицина: Підручник для студентів вищих медичних навчальних закладів III-IV рівнів акредитації. Вінниця: ДП «Державна картографічна фабрика», 2011. $928 \mathrm{c}$.

4. Волков В. І. Гендерні та вікові особливості ішемічної хвороби серця. Здоров'я Украӥни. 2007. № 12. Ч 1. С. 33-35.

DOI https://doi.org/10.30525/978-9934-26-075-9-29

\section{CURRENT UNDERSTANDING OF THE ACUTE KIDNEY INJURY PATHOGENESIS IN PATIENTS WITH COVID-19}

\author{
Khmelnov D. V. \\ $M D$, \\ Bilotserkivska station emergency medical care \\ Bila Tserkva, Kyiv region, Ukraine \\ Nykula B. T. \\ $M D$, \\ Kyiv Clinical Hospital on Railways Transport № 2 \\ Health Centre of JSC "Ukrainian railways" \\ Kyiv, Ukraine \\ Yelizarova O. T. \\ MD, Candidate of Medical Sciences, \\ Leading researcher of the Department of Public Health \\ SI «O.M. MarzeIev Institute for Public Health of the National Academy \\ of Medical Science of Ukraine» \\ Kyiv, Ukraine
}

Chronic Kidney Disease is one of the leading causes of Noncommunicable Diseases mortality [1, c.16]. An equally significant problem is Acute Kidney Injury (AKI) and, according to the WHO, about 4 million 
people die from this pathology a year [1, p. 16]. At the same time, infectious diseases increase the risk of nephrological pathology both in patients with already developed diseases and in previously healthy patients [1, p. 17]. Currently, the most widespread infectious disease affecting all age groups of the population is COVID-19. This disease, which initially manifests as an acute respiratory disease with interstitial and alveolar pneumonia, further affects various organs and systems with the involvement of receptors ACE2 [2, p. 67]. The kidneys also are the target organs. Kidney diseases, both as an independent disease and as a concomitant complication in diabetes mellitus, cardiovascular disease and other diseases, also leads to an increased risk of severe COVID-19 [3, p. 34; 4, p. 17; 5, p. 93]. Therefore, an understanding of the processes of the pathogenesis of kidney injury in patients with COVID-19 is necessary to provide adequate treatment.

The purpose of this keynote is to highlight the pathogenesis of acute kidney injury in patients with COVID-19.

Materials and methods. Searches were performed in the PubMed, Cochrane Library and Google Scholar databases for the keywords 'kidney dysfunctions + COVID-19', 'acute kidney injury + COVID-19' 'hemodialysis + COVID-19'.

Results. A study of the epidemiology of acute kidney injury (AKI) due to infection with SARS and MERS-CoV coronaviruses showed that this pathology was observed in 5-15\% of patients and was fatal in $60-90 \%$ of them. Based on these, researchers expected to see a similar prevalence in patients with COVID-19. Although the first publications demonstrated the presence of AKI in 3-9\% of patients with COVID-19 [2, p. 63], later it was determined that this pathology is more common. Thus, a study [6, p. 18] $(n=193)$ showed that already on the first day of hospitalization, a significant proportion of patients had signs of renal dysfunction, including 59\% with proteinuria, $44 \%$ with hematuria, $14 \%$ with an increased level of urea nitrogen in the blood and $10 \%$ with elevated serum creatinine levels. According to another survey $(\mathrm{n}=710)$ [7, p. 30] $43.9 \%$ of hospitalized patients with COVID-19 had proteinuria and hematuria. Elevated serum creatinine and urea levels were found in $14.4 \%$ and $13.1 \%$ of patients, respectively. Kaplan-Meier analysis demonstrated that patients with kidney disease had a significantly higher risk for in-hospital death. Coagulation pathway abnormalities, including prolonged activated partial thromboplastin time and higher D-dimer, were more common in patients with elevated baseline serum creatinine. During hospitalization, AKI occurred in $5.1 \%$ of patients. The incidence of AKI was significantly higher in patients with elevated baseline serum creatinine (11.9\%) than in patients with normal baseline values (4.0\%). According also to study [8, p. 37] 
kidney injury is common in coronavirus disease 2019, and it is associated with poor clinical outcomes.

The assumed mechanisms of AKI (Fig. 1) include both nonspecific mechanisms and specific for COVID (direct cellular damage as a result of viral penetration through the receptor ACE2 which is highly expressed in the kidney, imbalance of the renin-aldosterone-angiotensin system, the action of cytokines and thrombotic events) [4, p. 19; 7, p. 34; 9, p. 36; 10, p. 9]. Nonspecific mechanisms include hemodynamic changes, right ventricular failure, high levels of positive end-expiratory pressure in patients requiring mechanical ventilation, hypovolemia, nephrotoxic drugs, and sepsis.

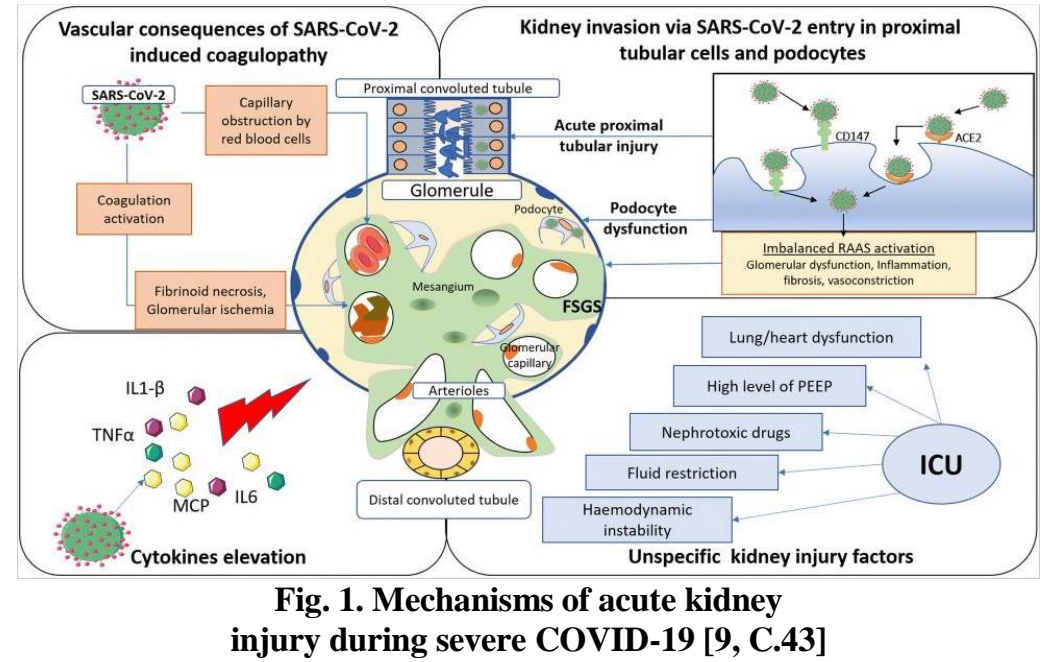

Dwell on the specific AKI mechanisms [10, p. 8-9]. There is direct infectious damage to tubular epithelial cells and podocytes with severe acute damage to the tubules by erythrocyte aggregation in severe COVID-19 [10, p. 8-9]. Direct kidney injury is observed in cytokine release syndrome, in the use of techniques such as ECMO invasive mechanical ventilation and/or CKRT, and hemophagocytic syndrome. Renal medullary hypoxia, compartment syndrome, tubular toxicity, type 1 cardiorenal syndrome develops due to damage to other organs in COVID-19. For example, cardiomyopathy/myocarditis, alveolar involvement, high peak airway pressure, intraabdominal hypertension, muscle fiber damage. Systemic effects of AKI include endothelial dysfunction, hypertension, hypervolemia, and damaged muscle fibers. 
Management of patients with AKI in COVID-19 includes general and supportive care, and, if necessary, renal replacement therapy (hemodialysis and peritoneal dialysis) [11, c.25-26]. If signs of AKI are detected, patients are recommended early hospitalization in intensive care units of the specialized hospitals. Supportive care, such as bed rest, nutritional and fluid support and maintenance of blood pressure and oxygenation, are important measures, as with all COVID-19 patients. Other measures include preventing and treating complications by providing organ support, maintaining hemodynamic stability and preventing secondary infection.

Conclusions. Therefore, about a third of patients with severe COVID-19 are at risk of developing acute kidney injury. The reasons for this are both the coronavirus SARS-CoV-2 and other specific and non-specific factors. Treatment of patients with acute kidney injury is carried out in intensive units taking into account all the identified pathologies.

\section{References:}

1. Luyckxa V., Tonelli M., Stanifer J. The global burden of kidney disease and the sustainable development goals Bulletin of the World Health Organization. 2018. Vol. 96. P. 414-422. doi: http://dx.doi.org/10.2471/BLT.17.206441

2. Wang D., Hu B., Hu C. et al. Clinical Characteristics of 138 Hospitalized Patients With 2019 Novel Coronavirus-Infected Pneumonia in Wuhan, China. JAMA. 2021. Vol.325(11). P. 1061-1069. doi: 10.1001/jama.2020.1585.

3. Williamson E.J., Walker A.J., Bhaskaran K. et al. Factors associated with COVID-19-related death using OpenSAFELY. Nature. 2020. Vol. 584(7821). P.430-436. doi: 10.1038/s41586-020-2521-4.

4. Ortiz-Prado E., Simbaña-Rivera K., Gómez-Barreno L. et al. Clinical, molecular, and epidemiological characterization of the SARS-CoV-2 virus and the Coronavirus Disease 2019 (COVID-19), a comprehensive literature review. Diagn Microbiol Infect Dis. 2020. Vol. 98(1). e115094. P. 1-32. doi: 10.1016/j.diagmicrobio.2020.115094.

5. Henry BM, Lippi G. Chronic kidney disease is associated with severe coronavirus disease 2019 (COVID-19) infection. Int Urol Nephrol. 2020. Vol.52(6). P.1193-1194. doi: 10.1007/s11255-020-02451-9.

6. Li Z., Wu M., Guo J. et al. Caution on kidney dysfunctions of 2019-nCoV patients. 2021. medRxiv. P. 1-25. https://doi.org/10.1101/ 2020.02.08.20021212. 
7. Cheng Y., Luo R., Wang K. et al. Kidney disease is associated with inhospital death of patients with COVID-19. Kidney Int. 2020. Vol. 97(5). P. 829-838. doi: 10.1016/j.kint.2020.03.005.

8. Zheng X., Yang H., Li X., Li H., et al. Prevalence of Kidney Injury and Associations with Critical Illness and Death in Patients with COVID-19. Clin J Am Soc Nephrol. 2020. Vol.15(11). P. 1549-1556. doi: 10.2215/ CJN.04780420.

9. Gabarre P., Dumas G., Dupont T., Darmon M., Azoulay E., Zafrani L. Acute kidney injury in critically ill patients with COVID-19. Intensive Care Med. 2020. Vol. 46(7). P.1339-1348. doi: 10.1007/s00134-020-06153-9.

10. Ronco C., Reis T. Kidney involvement in COVID-19 and rationale for extracorporeal therapies. Nat Rev Nephrol. 2020. Vol. 16(6). P.308-310. doi: 10.1038/s41581-020-0284-7.

11. Naicker S., Yang C.W., Hwang S.J., Liu B.C., Chen J.H., Jha V. The Novel Coronavirus 2019 epidemic and kidneys. Kidney Int. 2020. Vol. 97(5). P. 824-828. doi: 10.1016/j.kint.2020.03.001.

DOI https://doi.org/10.30525/978-9934-26-075-9-30

\title{
КОММУНИКАТИВНАЯ И КОНФЛИКТНАЯ КОМПЕТЕНТНОСТЬ ИНТЕРНОВ ЛЕЧЕБНОГО ПРОФИЛЯ
}

\author{
Хоботова Н. В. \\ кандидат медицинских наук \\ ассистент кафедры оториноларингологии \\ Днепровский государственный медииинский университет
}

Ехалов В. В.

кандидат медицинских наук,

доцент кафедры анестезиологии, интенсивной терапии и медицины неоткложных состояний Факультета последипломного образования Днепровский государственный медииинский университет

$$
\text { г. Днепр, Украина }
$$

Острота противоречий между качественными изменениями в медицине и установившимися в обществе моральными ценностями привела к формированию комплекса неоднозначных в этическом отношении проблем [1]. Этот процесс в области здравоохранения обусловлен рядом причин, которые являются следствием субъективных, 